
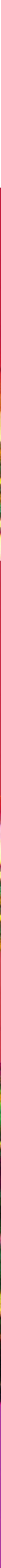
DiRECTEUR DE LA PUblication: Bruno David,

Président du Muséum national d'Histoire naturelle

RÉdACTEUR EN CHEF / EDITOR-IN-CHIEF: Didier Merle

ASSISTANTS DE RÉDACTION / AsSISTANT EDITORS: Emmanuel Côtez (geodiv@mnhn.fr); Anne Mabille

MISE EN PAGE / PAGE LAYOUT: Emmanuel Côtez

COMITÉ SCIENTIFIQUE / SCIENTIFIC BOARD:

Christine Argot (MNHN, Paris)

Beatrix Azanza (Museo Nacional de Ciencias Naturales, Madrid)

Raymond L. Bernor (Howard University, Washington DC)

Alain Blieck (USTL, Villeneuve d'Ascq)

Henning Blom (Uppsala University)

Jean Broutin (UPMC, Paris)

Gaël Clément (MNHN, Paris)

Ted Daeschler (Academy of Natural Sciences, Philadelphie)

Bruno David (MNHN, Paris)

Gregory D. Edgecombe (The Natural History Museum, Londres)

Ursula Göhlich (Natural History Museum Vienna)

Jin Meng (American Museum of Natural History, New York)

Brigitte Meyer-Berthaud (CIRAD, Montpellier)

Zhu Min (Chinese Academy of Sciences, Pékin)

Isabelle Rouget (UPMC, Paris)

Sevket Sen (MNHN, Paris)

Stanislav Štamberg (Museum of Eastern Bohemia, Hradec Králové)

Paul Taylor (The Natural History Museum, Londres)

COUVERTURE / COVER:

Réalisée à partir de la Figure 5B de cet article/created from Figure 5B of this article.

Geodiversitas est indexé dans / Geodiversitas is indexed in:

- Science Citation Index Expanded (SciSearch ${ }^{\circledR}$ )

- ISI Alerting Services ${ }^{\circledR}$

- Current Contents ${ }^{\circledR}$ / Physical, Chemical, and Earth Sciences ${ }^{\circledR}$

- Scopus ${ }^{\circledR}$

Geodiversitas est distribué en version électronique par / Geodiversitas is distributed electronically by:

- BioOne ${ }^{\circledR}$ (http://www.bioone.org)

Les articles ainsi que les nouveautés nomenclaturales publiés dans Geodiversitas sont référencés par / Articles and nomenclatural novelties published in Geodiversitas are referenced by:

- ZooBank ${ }^{\circledR}$ (http://zoobank.org)

Geodiversitas est une revue en flux continu publiée par les Publications scientifiques du Muséum, Paris Geodiversitas is a fast track journal published by the Museum Science Press, Paris

Les Publications scientifiques du Muséum publient aussi / The Museum Science Press also publish: Adansonia, Zoosystema, Anthropozoologica, European Journal of Taxonomy, Naturae.

Diffusion - Publications scientifiques Muséum national d'Histoire naturelle

CP $41-57$ rue Cuvier F-75231 Paris cedex 05 (France)

Tél. : 33 (0)1 40794805 / Fax: 33 (0)1 40793840

diff.pub@mnhn.fr / http://sciencepress.mnhn.fr

(C) Publications scientifiques du Muséum national d'Histoire naturelle, Paris, 2018

ISSN (imprimé / print): 1280-9659/ ISSN (électronique / electronic): 1638-9395 


\title{
Structural, functional, and physiological signals in ichthyosaur vertebral centrum microanatomy and histology
}

\author{
Alexandra HOUSSAYE \\ UMR 7179 CNRS, Muséum national d'Histoire naturelle, Département Adaptations du Vivant, \\ case postale 55, 57 rue Cuvier, F-75231 Paris cedex 05 (France) \\ and Steinmann Institut für Geologie, Paläontologie und Mineralogie, \\ Universität Bonn, 53115 Bonn (Germany) \\ houssaye@mnhn.fr (corresponding author) \\ Yasuhisa NAKAJIMA \\ Atmosphere and Ocean Research Institute, The University of Tokyo, 5-1-5 Kashiwanoha, \\ Kashiwa-shi, Chiba, 277-8564 (Japan) \\ and Steinmann Institut für Geologie, Paläontologie und Mineralogie, \\ Universität Bonn, 53115 Bonn (Germany) \\ ynakajima@um.u-tokyo.ac.jp \\ P. Martin SANDER \\ Steinmann Institut für Geologie, Paläontologie und Mineralogie, \\ Universität Bonn, 53115 Bonn (Germany) \\ martin.sander@uni-bonn.de
}

Submitted on 17 November 2017 | accepted on 27 November 2017 | published on 12 April 2018

urn:Isid:zoobank.org:pub:8E616364-0257-4DE6-96DC-4C2FE2F889C3

Houssaye A., Nakajima Y. \& Sander P. M. 2018. - Structural, functional, and physiological signals in ichthyosaur vertebral centrum microanatomy and histology. Geodiversitas 40 (7): 161-170. https://doi.org/10.5252/geodiversitas2018v40a7. http://geodiversitas.com/40/7

\section{ABSTRACT}

The first tuna-shaped amniotes evolved among ichthyosaurs, but this group exhibits in fact a wide diversity of morphologies and swimming modes. The histology and microanatomical features of vertebral centra of a diversity of ichthyosaur taxa from most basal to highly derived illustrating this variability were analyzed. The occurrence of unusual parallel fibered bone with platings of true parallel-fibered bone confirms high growth rate in all these taxa. Ichthyosaur vertebrae, which are deeply amphicoelous, show a limited endosteal territory associated with a limited growth in length. No bone mass increase nor decrease occurs. The vertebral centrum is spongious, and two microtypes are observed in the periosteal territory, with different degrees of organization of the trabecular network. The microtypes appear to be associated with the shape of the vertebral centrum, the organization of the spongiosa becoming homogeneous in the disk-shaped centra of cymbospondylids and Neoichthyosauria, rather

KEY WORDS

Ichthyosaur, vertebral centrum, histology,

microanatomy, microtype,

amphicoelous. than much more heterogeneous in spool-shaped centra of primitive Triassic forms. As opposed to what was previously suggested in other amniotes, the main switch in microanatomical organization appears thus to be correlated to the acquisition of deeply amphicoelous disk-like vertebral centra rather than to a shift in swimming mode from long and slender-bodied anguilliform swimmers to thunniform swimmers. 


\begin{abstract}
RÉSUMÉ
Signaux struturel, fonctionnel et physiologique dans la microanatomie et l'histologie du centrum vertébral des ichtyosaures.

Les premiers amniotes thunniformes ont évolué au sein des ichtyosaures, mais ce groupe présente en fait une large diversité de morphologies et de modes de nage. Les caractéristiques histologiques et microanatomiques du centrum vertébral de divers taxons d'ichtyosaures, des plus basaux aux plus dérivés, et illustrant cette variabilité, ont été analysées. La présence d'os à fibres parallèles inhabituel avec des placages d'os à fibres parallèles vrai confirme un taux de croissance élevé chez ces taxons. Les vertèbres d'ichtyosaures, qui sont très amphicoèles, montrent un territoire endostéal réduit associé avec une croissance en longueur limitée. Il n'y a ni augmentation, ni réduction de la masse des os. Le centrum vertébral est spongieux et deux microtypes sont observés dans le territoire périostique, avec des degrés divers d'organisation du réseau trabéculaire. Les microtypes semblent associés à la forme du centrum vertébral, l'organisation de la spongiosa devenant homogène dans les centrums en forme de disques des cymbospondylidés et des Neoichthyosauria, plutôt que bien plus hétérogène dans les centrums en forme de bobines des formes primitives du Trias. Contrairement à ce qui était précédemment suggéré chez les autres amniotes, le principal changement dans l'organisation microanatomique apparait donc corrélé à l'acquisition de centrums vertébraux très amphicoèles et en forme de disques plutôt qu'à un changement dans le mode de nage entre les nageurs anguilliformes à corps long et mince et les nageurs thunniformes.

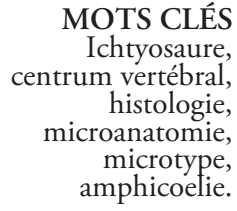

\section{INTRODUCTION}

Ichthyosaurs were one of the most successful groups of Mesozoic marine reptiles. They are the first amniote group that developed a thunniform mode of swimming, i.e., with propulsion only provided by a tail fluke (Sander 2000; McGowan \& Motani 2003; Motani 2009). The strong morphological convergence between derived ichthyosaurs (Neoichthyosauria) and modern dolphins and lamnid sharks underlies their high degree of adaptation to a fully open-marine lifestyle. However, ichthyosaurs in fact display a wide range of morphologies illustrating diverse ecological grades, from early forms with a long and slender body and a long and straight tail (cf. Utatsusaurus) that were probably anguilliform swimmers (Motani et al. 1996), to thunniform tuna-shaped forms with an upright bilobate tail on a narrow peduncle (cf. Ichthyosaurus; McGowan \& Motani 2003).

Ichthyosaur vertebrae display a neural arch and a centrum that are not fused. Vertebral centra are deeply amphicoelous (i.e., biconcave). Slightly elongated in primitive forms, they are particularly short (disk-like) in tuna-like forms (Sander 2000; Motani 2005).

Vertebral microanatomical features (i.e., the amount and distribution of the osseous tissue in the bone) have revealed themselves as encompassing an ecological signal and can be used to make paleoecological inferences about swimming abilities (Houssaye \& Bardet 2012; Dumont et al. 2013; Houssaye 2013; Houssaye et al. 2014a). Previous microanatomical and histological studies on ichthyosaurs analyzed mainly limb bones and ribs (e.g. Buffrénil et al. 1987; Buffrénil \& Mazin 1990; Kolb et al. 2011; Talevi et al. 2012; Talevi \& Fernández 2012; Nakajima et al. 2014; Houssaye et al. 2014b). Only a few old studies described the internal structure of vertebrae (e.g. Kiprijanoff 1881; Fraas 1891; Seitz 1907). The aim of this study is to analyze in more detail the vertebral centrum microanatomical patterns encountered in ichthyosaurs and notably to see if there is any variation between the primitive and the most derived forms.

\section{MATERIAL AND METHODS}

\section{Material}

The material analyzed for this study consists of cervical and dorsal vertebral centra of various ichthyosaurs (see Table 1) showing distinct morphologies and representing a wide range of taxa, from basal to derived ichthyosaurs (Fig. 1). These morphologies thus illustrate various modes of adaptation to an aquatic life (especially swimming modes). Some of the centra derive from articulated material (NSM PV 23854, LACM DI 158109, Nevada C, PIMUZ T 1296, PIMUZ T 2004), while others were found in isolation (Nevada A, B, $\mathrm{D}$, the Jurassic specimens).

Isolated ichthyosaur vertebral centra are relatively common in the fossil record, as compared to isolated long bones for example, and, as such, are of particular interest for comparative studies, especially destructive ones. Vertebral centra from different regions along the vertebral column vary in form and, especially, in the position of the facets for rib articulation (diapophyses and parapophyses), making it possible to approximately assign an isolated vertebral centum to a given region (McGowan \& Motani 2003).

In the Triassic specimens in this study, assignment to taxon was based on diagnostic features in the skeletons and isolated vertebrae as well as on stratigraphic age. Centra that are subequal in length and height or longer than high are restricted to ichthyosaurs more basal than Cymbospondylus Leidy, 1868, i.e., Grippioidea. Grippioid centra are also small, not exceeding 


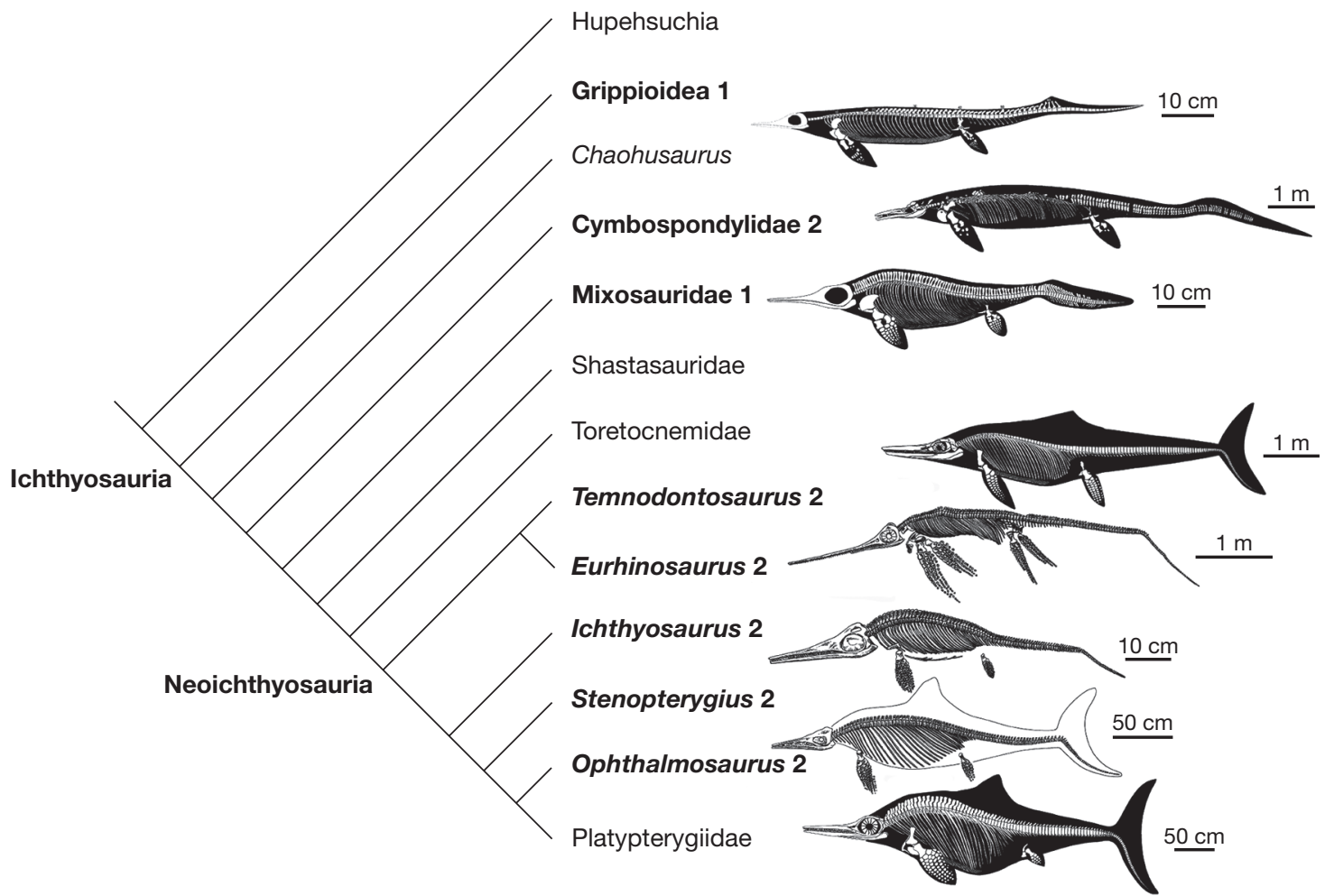

FIG. 1. - Consensus phylogenetic tree of Ichthyopterygia including (in bold) the taxa sampled for this study; modified from Ji et al. (2016); with associated silhouettes (from McGowan \& Motani 2003) and label of the microanatomical type encountered.

$4 \mathrm{~cm}$ in height. We assigned vertebrae meeting these criteria and being Early Triassic in age to this taxon (Table 1). There were also two isolated Middle Triassic vertebrae in our sample (Nevada B, D) that are elongate like the Early Triassic ones. Since they neither pertain to Cymbospondylidae nor to Mixosauridae, we also assigned them tentatively to Grippioidea. Nevada C can confidently be assigned to Cymbospondylus based on the anterior truncation of the single slanted rib articular facet in the dorsals (Sander 1992), large size, and Anisian age.

The Toarcian specimens from the SMNS collections we sectioned lack diagnostic features at the generic level but vary in size. We used the identifications provided to us in the early 1990s by the former curator of the marine reptile collection at the SMNS, Dr Rupert Wild. He presumably identified the vertebral material in comparison with complete skeletons, using the taxonomy available at the time. Thus, the material he identified as Stenopterygius Jaekel, 1904 could potentially also include the much rarer taxon Hauffiopteryx Maisch, 2008 which was described later (Maisch 2008).

\section{METHODS}

Most vertebral centra were physically sectioned using standard techniques along their mid-sagittal and neutral transverse planes (see Houssaye et al. 2008). The latter was easily identified as the one cutting the centrum core (point of minimal centrum length). In addition, conventional high-resolution computed tomography (GEphoenix|X-ray v| tome|xs 180 and 240; reconstructions performed using datox/res software) was used at the Steinmann Institute, University of Bonn (Germany) for the
Lower Triassic vertebral centra NMNS uncat. because of their rarity. Image segmentation and visualization were performed using VGStudioMax 2.2 (Volume Graphics Inc., Heidelberg, Germany). Scans of the physical thin sections were performed at high resolution (i.e., between 6400 and $12800 \mathrm{dpi}$ ) using an Epson V750-M Pro scanner. Centrum height and width were measured directly on the sagittal sections. The percentage of endochondral bone $(\% \mathrm{E})$, calculated as the ratio between the surface occupied by bone of endochondral origin and the total sectional area, was calculated based on the scans of the sagittal sections.

\section{RESULTS}

\section{MiCROANATOMICAL ORGANIZATION}

Sagittal sections are hourglass-shaped (Fig. 2). The periosteal (resulting from periosteal [centrigugal] ossification, at the outer surface of the bone) and endochondral (resulting from [centripetal] endochondral ossification, i.e., the substitution of preformed cartilage [being destroyed] by bony tissue) territories can clearly be identified: like in all amniote vertebral centra, the two cones of periosteal bone extend from the center of growth dorsally and ventrally, whereas the two cones of endochondral bone extend anteriorly and posteriorly (see e.g. Buffrénil et al. 2008). Not surprisingly, both territories are spongious (Figs 2, 3), though with a distinct organization (see below). Thus, all of the studied ichthyosaur vertebral centra lack compact bone. The periosteal territory occupies most of 
TABLE 1. - List of the material analysed for the current study, in phylogenetic order. Abbreviations: Pos, Position in vertebral colum; C, cervical vertebra; D, dorsal vertebra; aD, anterior dorsal vertebra; $\mathbf{p D}$, posterior dorsal vertebra; J, juvenile; SS, sagittal section; TS, transverse section; $\mathbf{C H}$, centrum height; \%E, relative percentage of endochondral bone; L/H, length over height; MT, microanatomical type; LACM, Natural History Museum of Los Angeles County; NSM, National Museum of Nature and Science, Tokyo; PIMUZ, Paläontologisches Institut und Museum, Universität Zürich, Switzerland; SMNS, Staatliches Museum für Naturkunde Stuttgart, Germany. Symbol: *, intermediate between 1 and 2 .

\begin{tabular}{|c|c|c|c|c|c|c|c|c|c|}
\hline Taxon & Coll. nb. & Locality/Stratigraphy & Pos. & SS & TS & $\mathrm{CH}$ & $\% \mathrm{E}$ & $\mathrm{L} / \mathrm{H}$ & MT \\
\hline Grippioidea & NSM PV 23854 & $\begin{array}{l}\text { Zhitkov Formation, Neocolumbites zone, middle Spathian, } \\
\text { Lower Triassic, Zhitkov Cape, South Primorye, Russia }\end{array}$ & $\mathrm{D}$ & $x$ & $x$ & 22.9 & - & 1.07 & 1 \\
\hline $\begin{array}{l}\text { Grippioidea, same } \\
\text { individual as above }\end{array}$ & NSM PV 23854 & $\begin{array}{l}\text { Zhitkov Formation, Neocolumbites zone, middle Spathian, } \\
\text { Lower Triassic, Zhitkov Cape, South Primorye, Russia }\end{array}$ & $\mathrm{D}$ & $x$ & $x$ & 24.2 & - & 0.82 & 1 \\
\hline $\begin{array}{l}\text { Grippioidea - } \\
\quad \text { Nevada A }\end{array}$ & LACM uncat. & $\begin{array}{l}\text { Tobin Formation, Subcolumbites zone, late Spathian, Lower } \\
\text { Triassic, Augusta Mountains, Nevada, USA }\end{array}$ & $?$ & $x$ & $x$ & 28.0 & 49.0 & 0.74 & 1 \\
\hline $\begin{array}{l}\text { ?Grippioidea - } \\
\text { Nevada B }\end{array}$ & LACM uncat. & $\begin{array}{l}\text { Fossil Hill Member, Favret Formation, Anisian, Middle } \\
\text { Triassic, Favret Canyon, Augusta Mountains, Nevada, USA }\end{array}$ & $?$ & $x$ & $x$ & 28.3 & - & 1.20 & 1 \\
\hline $\begin{array}{l}\text { ?Grippioidea - } \\
\text { Nevada D }\end{array}$ & LACM uncat. & $\begin{array}{l}\text { Fossil Hill Member, Favret Formation, Anisian, Middle } \\
\text { Triassic, Favret Canyon, Augusta Mountains, Nevada, USA }\end{array}$ & $?$ & $x$ & $\times$ & 33.5 & - & 0.73 & 1 \\
\hline $\begin{array}{l}\text { ?Cymbospondylidae } \\
\text { new taxon A, } \\
\text { mother }\end{array}$ & LACM DI 158109 & $\begin{array}{l}\text { upper part of Fossil Hill Member, Favret Formation, Anisian, } \\
\text { Middle Triassic, Favret Canyon, Augusta Mountains, } \\
\text { Nevada }\end{array}$ & $\mathrm{D}$ & $x$ & $x$ & 42.0 & - & 0.56 & 2 \\
\hline $\begin{array}{l}\text { ?Cymbospondylidae } \\
\text { new taxon } A \text {, fetus }\end{array}$ & LACM DI 158109 & $\begin{array}{l}\text { upper part of Fossil Hill Member, Favret Formation, Anisian, } \\
\text { Middle Triassic, Favret Canyon, Augusta Mountains, Nevada }\end{array}$ & $\mathrm{D}$ & $x$ & $x$ & 14.4 & - & 0.62 & * \\
\hline $\begin{array}{l}\text { Cymbospondylus sp. } \\
\text { - Nevada C }\end{array}$ & LACM uncat. & $\begin{array}{l}\text { upper part of Fossil Hill Member, Favret Formation, Anisian, } \\
\text { Middle Triassic, Favret Canyon, Augusta Mountains, Nevada }\end{array}$ & $\mathrm{D}$ & $x$ & $x$ & 89.0 & - & 0.47 & 2 \\
\hline Mixosaurus sp. & PIMUZ T 2004 & $\begin{array}{l}\text { Besano Formation, latest Anisian, Middle Triassic, Monte } \\
\text { San Giorgio, Ticino, Switzerland }\end{array}$ & $?$ & $x$ & $x$ & 9.0 & 34.4 & 0.66 & 1 \\
\hline Mixosaurus sp. & PIMUZ T 1296 & $\begin{array}{l}\text { Besano Formation, latest Anisian, Middle Triassic, Monte } \\
\text { San Giorgio, Ticino, Switzerland }\end{array}$ & $?$ & $x$ & $x$ & - & - & - & 1 \\
\hline $\begin{array}{l}\text { Temnodontosaurus } \\
\text { sp. }\end{array}$ & SMNS uncat. & $\begin{array}{l}\text { Posidonienschiefer Formation, Toarcian, Lower Jurassic, } \\
\text { Holzmaden area, Germany }\end{array}$ & $\mathrm{C} ?$ & $x$ & $x$ & 69.0 & 19.0 & 0.67 & 2 \\
\hline Eurhinosaurus sp. & SMNS 50913 & $\begin{array}{l}\text { Posidonienschiefer Formation, Toarcian, Lower Jurassic, } \\
\text { Zell unter Aichelberg, Germany }\end{array}$ & $\mathrm{pD}$ & $x$ & $x$ & 74.0 & 21.0 & 0.50 & 2 \\
\hline Ichthyosaurus sp. & SMNS 13080 & $\begin{array}{l}\text { Lias, Hettangian or Sinemurian, Lower Jurassic, Lyme } \\
\text { Regis, England }\end{array}$ & $\mathrm{pD}$ & $x$ & $x$ & 32.0 & 38.9 & 0.60 & 2 \\
\hline $\begin{array}{l}\text { small thunnosaurian } \\
\text { ichthyosaur, } \\
\text { probably } \\
\text { Stenopterygius }\end{array}$ & $\begin{array}{l}\text { SMNS uncat. } \\
\text { SMNS uncat. } \\
\text { SMNS uncat. }\end{array}$ & $\begin{array}{l}\text { Posidonienschiefer Formation, Toarcian, Lower Jurassic, } \\
\text { Holzmaden area, Germany }\end{array}$ & $\begin{array}{l}\mathrm{C}, \mathrm{J} \\
? \\
?\end{array}$ & $\begin{array}{l}\times \\
- \\
\times\end{array}$ & $\begin{array}{l}\times \\
\times \\
-\end{array}$ & $\begin{array}{l}19.0 \\
- \\
52.0\end{array}$ & $\begin{array}{c}45.2 \\
- \\
36.1\end{array}$ & $\begin{array}{c}0.51 \\
- \\
0.50\end{array}$ & $\begin{array}{l}2 \\
2 \\
2\end{array}$ \\
\hline Ophthalmosaurus sp. & SMNS uncat. & Oxford Clay, Callovian, Middle Jurassic, England & $\mathrm{aD}$ & $\times$ & $x$ & 79.0 & 24.6 & 0.48 & 2 \\
\hline
\end{tabular}

the section. The relative proportion of the endochondral territory varies according to taxon (from 19 to $49 \%$; see $\% \mathrm{E}$ in Table 1). The transverse sections essentially correspond to the periosteal territory because they were cut through the center of the centrum. However, paired cone-shaped territories spread from the centrum core towards the facets for articulation with the neural arch and the ribs, similar to what is observed in shark vertebral centra (Romer 1961: 172, fig. 99).

Two main organizations can be observed: a) Microtype 1. In these vertebral centra (see Table 1; Fig. 2A-D), the spongiosa in the periosteal territory is not homogeneous and intertrabecular spaces are relatively large. Trabeculae are not well organized despite a roughly dominantly radial and sagittal orientation in transverse and sagittal sections, respectively; trabeculae are of various thicknesses so that intertrabecular spaces are randomly sized and shaped; and b) Microtype 2 . In these vertebral centra the trabeculae are essentially oriented along the sagittal plane. The difference in main orientation in the two microtypes is obvious in transverse section where the radial orientation of the trabeculae in microtype 1 is replaced by a circumferential one in microtype 2 . In this microtype, the spongiosa is relatively homogeneous with fairly regularly dorsoventrally spaced thin trabeculae and reduced intertrabecular spaces. In longitudinal section, the endochondral territory is strictly limited to the anterior and posterior borders of the centrum, i.e., its intervertebral articular surfaces (Fig. 2G). In transverse section, the inner organization of the vertebral centra clearly evokes a honeycomb (Fig. 2H).

Although there seems to be a size effect in this microtype distinction (significant correlation when only adult specimens are taken into consideration - but small sample size), the largest vertebral centra showing the highest degree of organization, it is clearly not the unique factor. Indeed, the Ichthyosaurus sp. (as in Fig. 2F-G) and LACM uncat. Grippioidea indet. Nevada D (Fig. 2C, D), despite showing a similar centrum height, clearly show distinct microanatomical organizations, suggesting that there is also a taxon-specific effect.

Juvenile material was available for two taxa: Stenopterygius and a still undescribed Middle Triassic ichthyosaur, for which a fetus is preserved inside an adult skeleton. In the case of the Stenopterygius vertebral centrum, the material, although from the same locality, was not found associated and the isolated vertebral centrum can only be identified at the genus level. A clear change in microanatomical organization is observed between the fetal/juvenile and adult specimens, with a strong increase in the tightness of the spongiosa with size (Fig. 3). The surface 


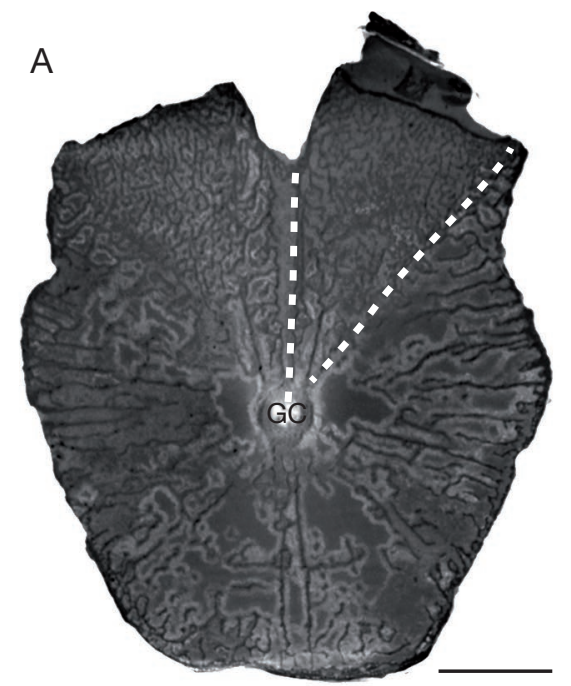

B

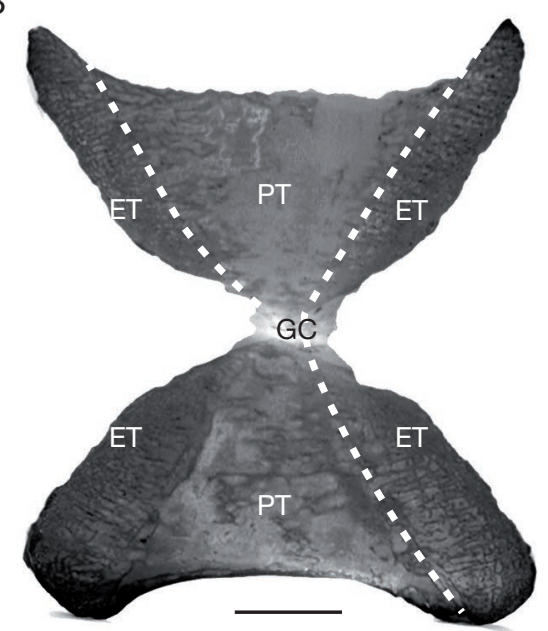

C

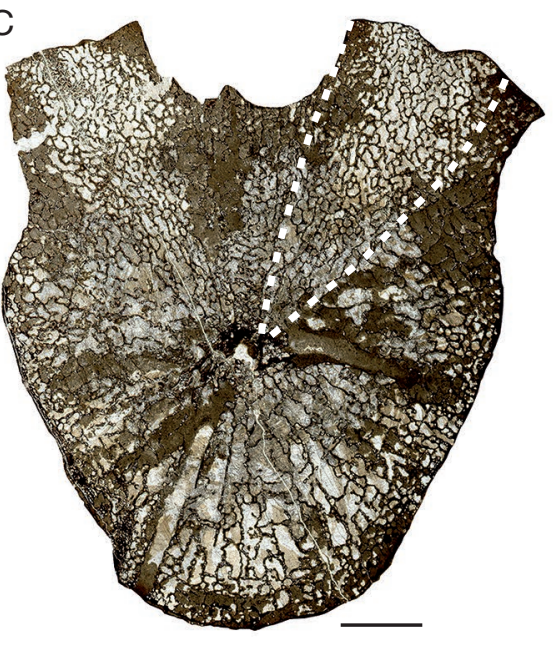

D
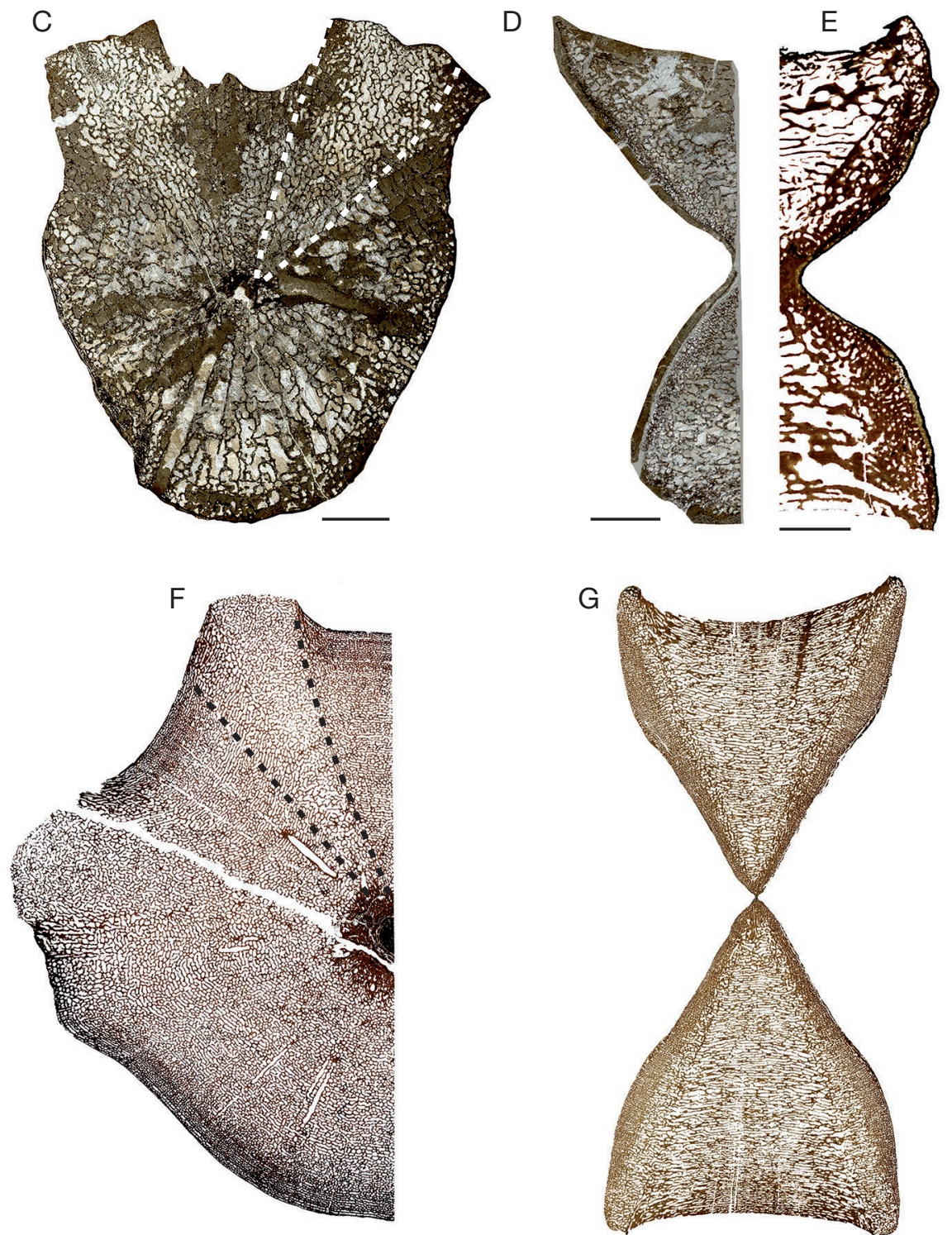

G

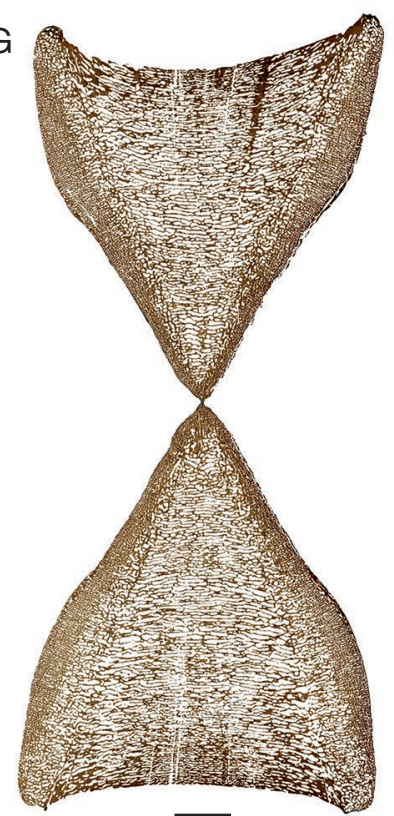

FIG. 2. - Virtual (A, B) and classical (C-G) sections of ichthyosaur vertebral centra illustrating the microanatomical types 1 (A-E) and 2 (F, G): A, B, Grippioidea indet., Lower Triassic, Russia, NSM PV 23854; C, D, Grippioidea indet., Middle Triassic, Nevada, LACM uncat. Nevada; D, E, Mixosaurus sp. PIMUZ T 2004; F, Temnodontosaurus sp. half transverse section; G, Eurhinosaurus sp. SMNS 50913 sagittal section; A, C, F, transverse sections; B, D, E, G, sagittal (and half mid-sagittal) sections. Abbreviations: GC, growth center; ET, endochondral territory; PT, periosteal territory. Scale bars: 5 mm. 

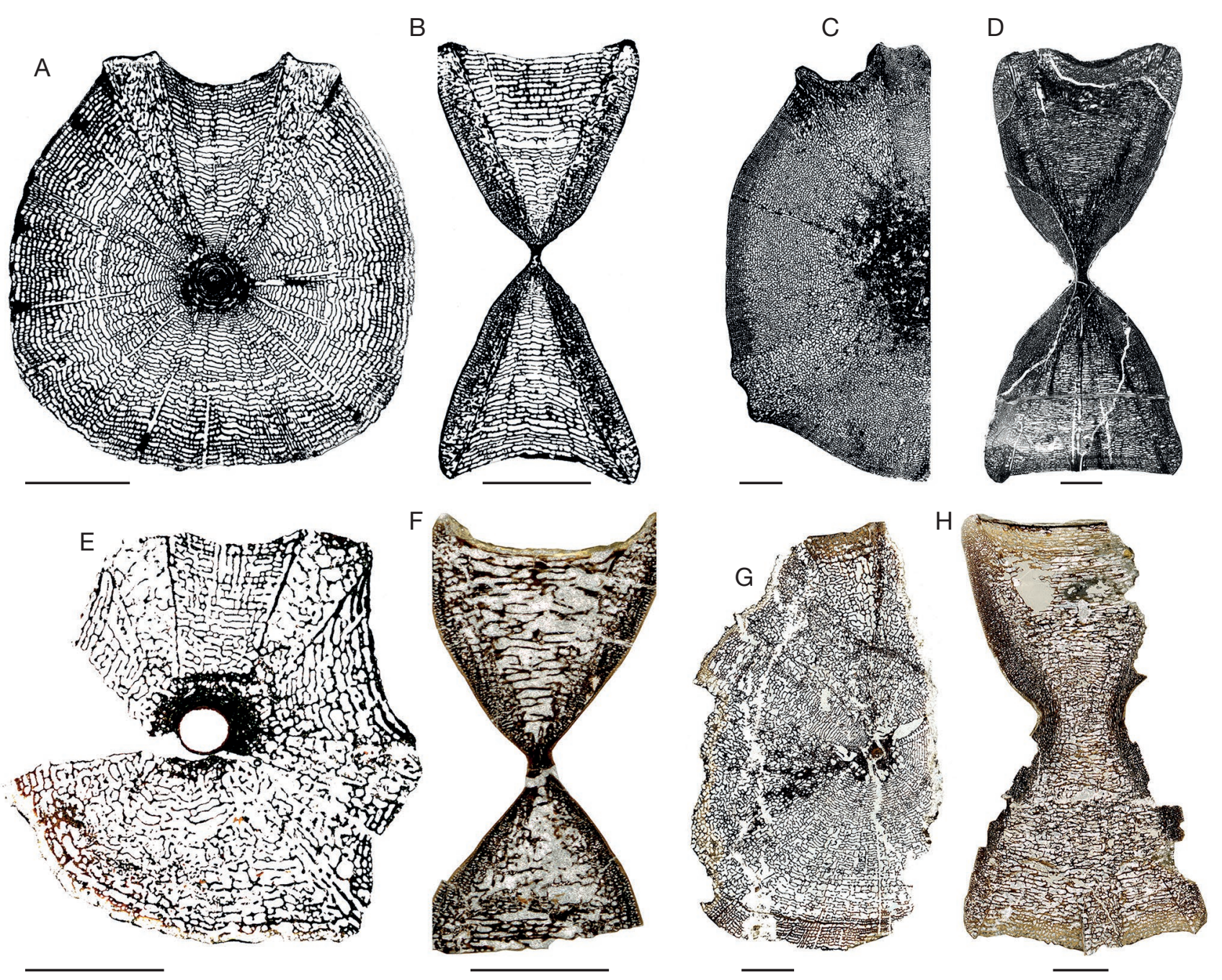

FIG. 3. - Classical sections of ichthyosaur vertebral centra illustrating the intraspecific size variation (interpolated as possible ontogenetic variation): A-D, Stenopterygius sp.; A, B, juvenile vertebra SMNS uncat.; C, D, adult vertebra SMNS uncat.; E-H, Ichthyosauria new taxon A, Middle Triassic, Nevada, LACM 8031; E, F, fetal vertebra LACM DI 158109; G, H, adult vertebra DI 158109; A, C, E, G, transverse (and half-transverse) sections; B, D, F, H, sagittal sections. Scale bars: $5 \mathrm{~mm}$.

occupied by bone of endochondral origin is higher in the fetal/ juvenile specimens than in adult specimens (45.2\% vs $36.1 \%$ in Stenopterygius; $33.2 \%$ and $33.7 \%$ [two sections] vs $28.7 \%$ in the undescribed Middle Triassic specimen).

\section{HistOLOGICAL FEATURES}

In the endochondral territory, the centrum anterior and posterior borders naturally exhibit calcified cartilage cells (Fig. 4A). From these surfaces, trabeculae are naturally oriented, in continuity with the cartilaginous cells, approximately perpendicular to the articular surface (Fig. 4A). However, this primary orientation is modified by bone deposits partly filling the intertrabecular spaces, so that the organization of the spongiosa becomes less homogeneous in the endochondral territory away from the bone anterior and posterior borders (Fig. 4B). The osseous trabeculae are essentially made of a core of fibrous bone with linings of parallel-fibered bone (Fig. 4C). Remodeling is limited, although a few secondary osteons can sometimes occur (Fig. 4C). In the periosteal territory, bone trabeculae essen- tially consist of unusual parallel-fibered bone sensu Houssaye et al. (2013) (i.e., with large and randomly shaped osteocyte lacunae [as in fibrous bone]; Fig. 4D-F). With the additional deposits of parallel-fibered bone in the intertrabecular spaces, this tissue evokes fibrolamellar bone (Fig. 4D-F) without truly corresponding to this tissue type, since there is no true fibrous bone. Numerous Sharpey's fibers insert between the two territories, following the direction of the limit between the territorial (periosteal and endochondral) cones (Fig. 5A). Around the center of the centrum, that is in its antero-posteriorly thinnest portion, bone histological features are different from the above descriptions. In parasagittal sections, slightly away from the perfect mid-sagittal plane, periosteal bone consists of true parallel-fibered bone (Fig. 5B, C). The organization is much more compact than in the rest of the bone. Remodeling occurs in the center of the section (Fig. 5B, C). This is in accordance with the observation, in transverse sections, of a ring of more compact periosteal deposits of parallel-fibered bone surrounding the centrum core (notochordal canal; Fig. 5D). 

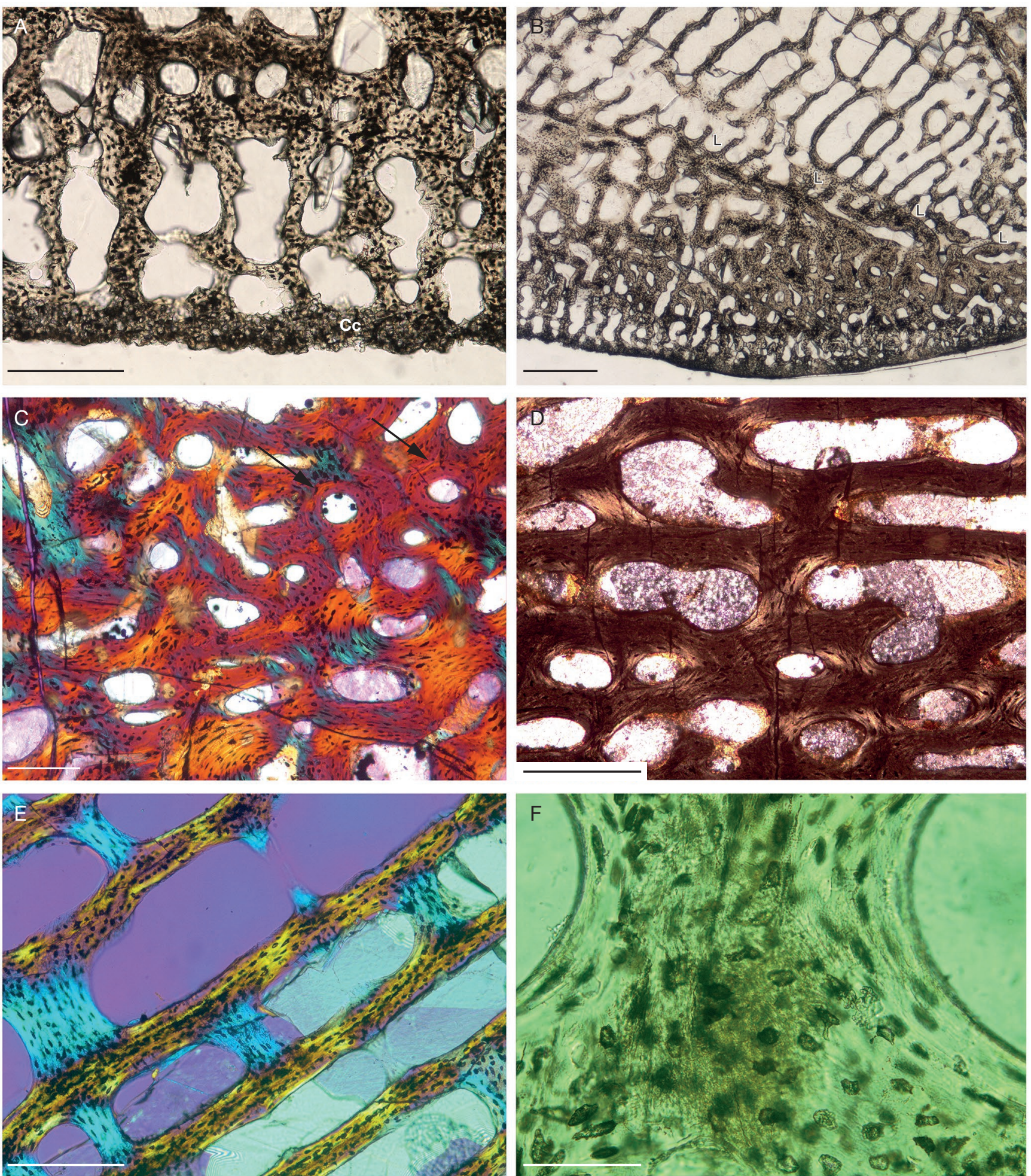

FIG. 4. - Histological features of ichthyosaur vertebral centra: A, B, E, F, Stenopterygius sp. SMNS uncat. longitudinal section; C, Stenopterygius sp. SMNS uncat. longitudinal section; D, Temnodontosaurus sp. SMNS uncat. longitudinal section; $\mathbf{A}$, cartilaginous cells (Cc) and osseous trabeculae in the periphery of the endochondral territory in natural light (NL); articular surface at the bottom; B, illustration of the change of organization/orientation of the trabeculae from the periphery (bottom) to the core of the endochondral territory and limit (L) with the peripheral territory (from bottom to top) in NL; C, inner endochondral bone showing some degree of remodelling in polarized light (PL) with gypsum filter; arrows point to secondary osteons; D, E, unusual parallel fibered bone with platings of parallel-fibered bone in the periosteal territory in PL (D) and additional gypsum filter (E); $\mathbf{F}$, core of a trabeculae of unusual parallel fibered bone showing the large randomly shaped osteocyte lacunae and the elongated cells in the platings of parallelfibered bone in NL. Scale bars: A, D, E, $200 \mu \mathrm{m} ; \mathrm{B}, \mathrm{C}, 500 \mu \mathrm{m} ; \mathrm{F}, 50 \mu \mathrm{m}$. 

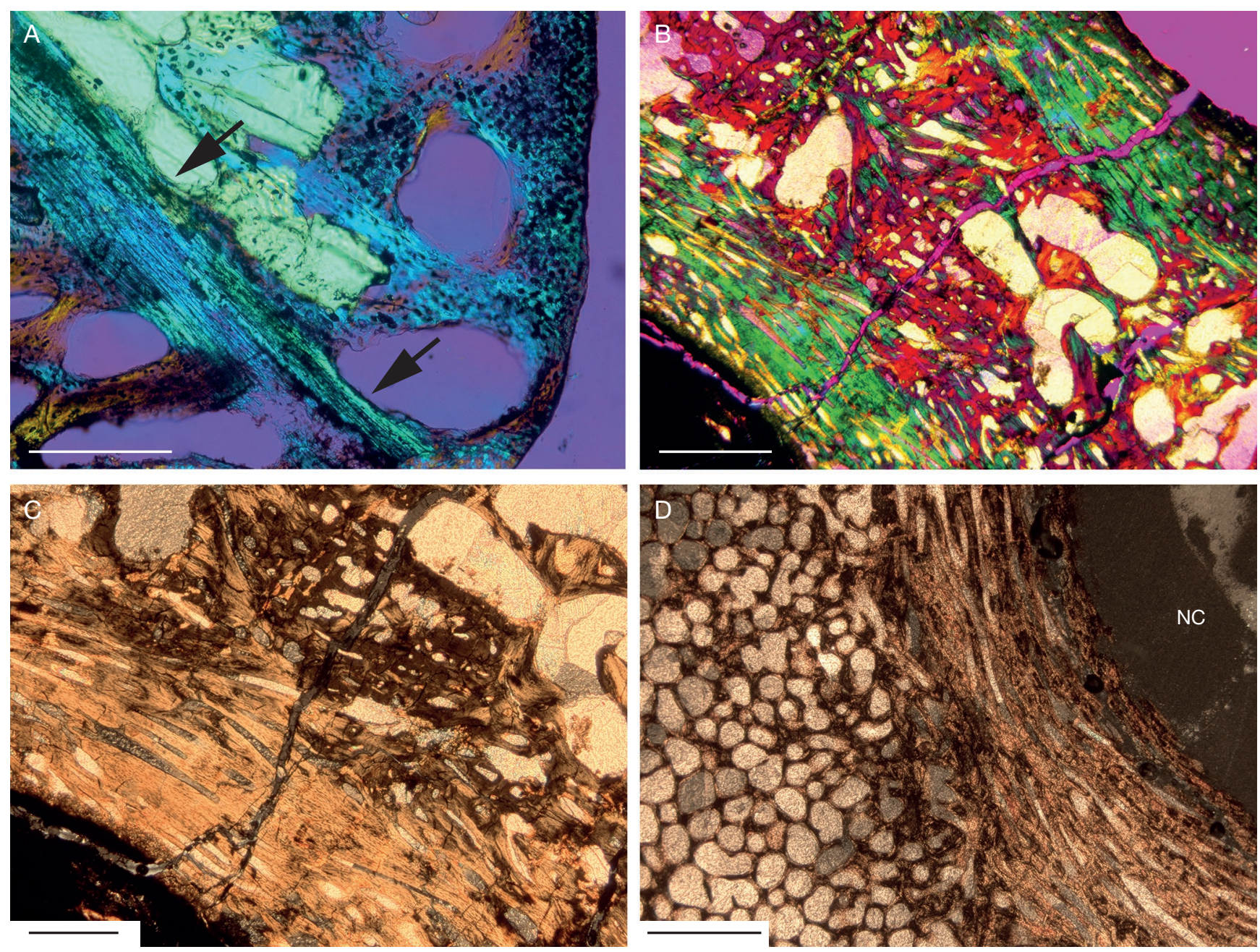

FIG. 5. - Histological features of ichthyosaur vertebrae: A, Stenopterygius sp. SMNS uncat. Longitudinal section. Numerous Sharpey's fibers at the limit between the periosteal (left) and endochondral (right) territories in PL with gypsum filter; pointed by arrows; B, C, Temnodontosaurus sp. SMNS uncat. parasagittal section showing the compact deposits of parallel-fibered bone (blue) in the outer core of the vertebra and secondary bone (red) in its inner core in PL with gypsum filter (B) and NL (C); D, Temnodontosaurus sp. SMNS uncat. Transverse section showing on the right the layer of rather compact parallel-fibered bone lining the centrum core (NC, notochordal canal), whereas the rest of the centrum is spongious (left) in NL. Scale bars: A, $200 \mu \mathrm{m} ; \mathrm{B}, \mathrm{D}, 1 \mathrm{~mm} ; \mathrm{C}, 500 \mu \mathrm{m}$.

\section{DISCUSSION}

\section{GROWTH FEATURES}

Ichthyosaur vertebral centra are characterized by an extremely limited endochondral territory, as compared to other known amniote vertebral centra. In Cymbospondylidae and ichthyosaurs more derived than mixosaurs, growth in length of the vertebral centrum, as compared to growth in diameter, was extremely limited, conferring upon them their typical "hockey puck" disk shape.

Primary bone deposits consist of unusual parallel fibered bone with platings of true parallel-fibered bone, mimicking a fibro-lamellar complex. This shows that growth was quick in these taxa, although slightly slower than in long bones, where true fibro-lamellar bone is observed (Kolb et al. 2011; Houssaye et al. 2014b).

The spongiosa is of primary origin, as in long bones, and not resulting from primary bone resorption (see Houssaye et al. 2014b contra Buffrénil \& Mazin 1990).
STRUCTURAL REQUIREMENTS

All ichthyosaur vertebral centra are deeply amphicoelous. Our observations highlight the occurrence of a local increase in bone deposits surrounding the centrum growth center, circumferentially, probably reinforcing the bone and preventing any breakage in this thin region.

\section{MECHANICAL ROLE}

As opposed to what was described for some ribs (Talevi \& Fernández 2012; Massare et al. 2014) and long bones (Houssaye et al. 2014b), no general or local increase in bone compactness is observed in ichthyosaur vertebral centra, which are exclusively spongious, as compared to what is observed in most amniotes (Houssaye et al. 2014a). As noted above, there is no peripheral layer of compact cortex as in most amniotes (Dumont et al. 2013; Hayashi et al. 2013; Houssaye et al. 2014b). This is not specific to ichthyosaurs and has been documented in several aquatic amniotes (Hayashi et al. 2013; Dumont et al. 2013; Hous- 
saye et al. 2016). Compactness appears slightly lower than in mosasaurs (Houssaye \& Bardet 2012) but not particularly low as compared to other amniotes (Houssaye et al. 2014b, 2016). Vertebral centra are lightly built but not extremely light and so do not show an osteoporotic-like pattern.

Trabeculae are essentially sagittaly oriented, i.e., in the direction of maximum stress (Fig. 2B, E, G). The limited remodelling suggests that the primary organization is optimized for functional requirements even later in life. There is a strong increase in the number of trabeculae during ontogeny (observed in microtype 2 vertebral centra) and evolution. The increase in the tightness (i.e., smaller intertrabecular spaces and thinner trabeculae) of the spongiosa through ontogeny and with taxon size is consistent with the trend already described in mosasaurs (Houssaye \& Tafforeau 2012) and amniotes in general (Houssaye et al. 2010; Dumont et al. 2013). The two main microtypes here described for ichthyosaur vertebral centra seem to rather follow the evolutionary history of the group (except for Cymbospondylus; Fig. 1). The less organized and looser spongiosa is observed in the most primitive ichthyosaur forms: the Lower Triassic Russian vertebral centra and the Lower and Middle Triassic indet. Grippioidea specimens from Nevada. These specimens also correspond to proportionally longer vertebral centra $(0.66<\mathrm{L} / \mathrm{H}<1.2$ vs $0.47<\mathrm{L} / \mathrm{H}<0.67)$, and they show the highest calculated percentages of endochondral bone in adult specimens (Table 1 ).

As noted, more derived ichthyosaurs have disk-shaped vertebral centra that are distinctly shorter than tall (Sander 2000; McGowan \& Motani 2003). This is the case for all the Jurassic Neoichthyosauria in our sample but also for Cymbospondylus with vertebral centra showing a length/ height ratio up to 1:3. However, the Neoichthyosauria have fewer vertebrae (around 45 presacrals) than the Triassic cymbospondylid and shastasaurid ichthyosaurs (commonly > 60 presacrals; Sander 2000; McGowan \& Motani 2003; Sander et al. 2011).

These various observations suggest a joint shift in vertebral centrum anatomical and microanatomical features between primitive ichthyosaurs with spool-shaped vertebral centra and more derived ones (and Cymbospondylus) with disk-shaped vertebral centra. However, microanatomy does not appear to correlate with body shape and swimming style because it is essentially the same in the long and slender-bodied cymbospondylids and tuna-shaped neoichthyosaurs.

An increase in the length (assumed total length of all trabeculae placed end to end) of the trabecular network in large pelagic oscillators is hypothesized to enable vertebral centra to better resist the extreme mechanical stresses they have to face (Dumont et al. 2013). However, our results seemingly falsify this hypothesis, suggesting a more simple relationship between vertebral centrum proportions and microanatomy instead, in ichthyosaurs, possibly resulting from morphogenesis of the disk-shaped vertebral centra that was achieved by faster osteogenesis in the periosteal domain compared to the endochondral domain.

\section{Acknowledgements}

We are very grateful to Rupert Wild and Rainer Schoch (Staatliches Museum für Naturkunde Stuttgart, Stuttgart, Germany) and Heinz Furrer (Paläontologisches Institut und Museum der Universität, Zurich, Switzerland), Yasunari Shigeta (National Museum of Nature and Science, Tsukuba, Japan), and Maureen Walsh (Natural History Museum of Los Angeles County, Los Angeles, USA) for the loan of specimens and permission to section them, and to Olaf Dülfer and Rebecca Hofmann (Steinmann-Institut, Universität Bonn, Bonn, Germany) for the preparation of casts and thin sections. We thank two anonymous reviewers and Erin Maxwell (Staatliches Museum für Naturkunde, Stuttgart) for helpful comments that improved the manuscript. We thank the Steinmann Institut (University of Bonn, Germany) for providing access to the micro-CT scanner and for support. A.H. acknowledges financial support from the A. v. Humboldt Foundation and the ANR-13-PDOC-0011.

\section{REFERENCES}

Buffrénil V. DE \& Mazin J.-M. 1990. — Bone histology of the Ichtyosaurs: Comparative data and functional interpretation. Paleobiology 16: 435-447. https://doi.org/10.1017/ S0094837300010174

BufFRÉNIL V. DE, MAZIN J.-M. \& RiCQLES A. DE 1987. — Caractères structuraux et mode de croissance du fémur d'Omphalosaurus nisseri, ichthyosaurien du Trias moyen du Spitzberg. Annales de Paléontologie 73: 195-216.

Buffrénil V. de, Bardet N., Pereda-Suberbiola X. \& Bouya B. 2008. - Specialization of bone structure in Pachyvaranus crassispondylus Arambourg, 1952, an aquatic squamate from the Late Cretaceous of the southern Tethyan margin. Lethaia 41: 59-69. https://doi.org/10.1111/j.1502-3931.2007.00042.x

Dumont M., Laurin M., Jacques F., Pellé E., Dabin W. \& BUFFRÉNIL V. DE 2013. - Inner architecture of vertebral centra in terrestrial and aquatic mammals: a two-dimensional comparative study. Journal of Morphology 274: 570-84. https://doi. org/10.1002/jmor.20122

FRAAS E. 1891. - Die Ichthyosaurier der süddeutschen Trias- und Jura-Ablagerungen. H. Laupp, Tübingen, 81 p.

Hayashi S., Houssaye A., NaKajima Y., Chiba K., Ando T., SaWAMURA H., INUZUKa N., KANEKO N. \& OSAKI T. 2013. Bone inner structure suggests increasing aquatic adaptations in Desmostylia (Mammalia, Afrotheria). PLoS ONE 8: e59146. https://doi.org/10.1371/journal.pone.0059146

Houssaye A. 2013. - Palaeoecological and morphofunctional interpretation of bone mass increase: an example in Late Cretaceous shallow marine squamates. Biological Reviews 88: 117-139. https://doi.org/10.1111/j.1469-185X.2012.00243.x

HOUSSAYE A. \& BARDET N. 2012. - Rib and vertebral microanatomical characteristics of hydropelvic mosasauroids. Lethaia 45: 200-209. https://doi.org/10.1111/j.1502-3931.2011.00273.x

HOUSSAYE A. \& TAFFOREAU P. 2012. - What vertebral microanatomy reveals about the ecology of juvenile mosasaurs (Reptilia, Squamata). Journal of Vertebrate Paleontology 32: 1042-1048. https://doi.org/10.1080/02724634.2012.680999

Houssaye A., Buffrénil V. De, Rage J.-C. \& Bardet N. 2008. An analysis of vertebral "pachyostosis" in Carentonosaurus mineaui (Mosasauroidea, Squamata) from the Cenomanian (early Late Cretaceous) of France, with comments on its phylogenetic and functional significance. Journal of Vertebrate Paleontology 28: 685-691. https:// doi.org/10.1671/0272-4634(2008)28[685:AAOVPI]2.0.CO;2 
Houssaye A., Mazurier A., Herrel A., Volpato V., Tafforeau P., BOISTEL R. \& BUFFRÉNIL V. DE 2010. — Vertebral microanatomy in squamates: structure, growth and ecological correlates. Journal of Anatomy 217: 715-727. https://doi.org/10.1111/j.14697580.2010.01307.x

Houssaye A., Lindgren J., Pellegrini R., Lee A. H., GerMAIN D. \& POLCYN M. J. 2013. - Microanatomical and histological features in the long bones of mosasaurine mosasaurs (Reptilia, Squamata) - Implications for aquatic adaptation and growth rates. PLoS ONE 8: e76741. https://doi.org/10.1371/ journal.pone.0076741

Houssaye A., Tafforeau P. \& Herrel A. 2014a. - Amniote vertebral microanatomy - what are the major trends? Biological Journal of the Linnean Society 112: 735-746. https://doi. org/10.1111/bij.12311

Houssaye A., Scheyer T. M., Kolb C., Fischer V. \& Sander P. M. 2014b. - A new look at ichthyosaur long bone microanatomy and histology: Implications for their adaptation to an aquatic life. PLoS ONE 9: e95637. https://doi.org/10.1371/ journal.pone.0095637

Houssaye A., SAnder P. M. \& Klein N. 2016. — Adaptive patterns in aquatic amniote bone microanatomy - More complex than previously thought. Integrative \& Comparative Biology 56 1349-1369. https://doi.org/10.1093/icb/icw120

JAEKEL O. 1904. - Die Wirbeltiere. Eine Übersicht über die fossilen und lebenden Formen. Gebrüder Borntraeger, Berlin, VIII + 252 p.

Ji C., Jiang D.-Y., Motani R., Rieppel O., HaO W.-C. \& Sun Z.-Y. 2016. - Phylogeny of the Ichthyopterygia incorporating the recent discoveries from South China. Journal of Vertebrate Paleontology 36: e1025956. https://doi.org/10.1080/02724634.2015.1025956

KIPRIJANOFF W. 1881. — Studien über die Fossilen Reptilien Russlands. Theil 1. Gattung Ichthyosaurus König aus dem Sewerischen Sandstein oder Osteolith der Kreide-Gruppe. Mémoires de l'Académie impériale des Sciences, St Petersbourg, vol. 28: 1-103.

Kolb C., SÁncheZ-Villagra M. R. \& SCheyer T. M. 2011. - The palaeohistology of the basal ichthyosaur Mixosaurus (Ichthyopterygia, Mixosauridae) from the Middle Triassic: Palaeobiological implications. Comptes Rendus Palevol 10: 403-411. https://doi. org/10.1016/j.crpv.2010.10.008

LEIDY J. 1868. - Notice of some reptilian remains from Nevada. Proceedings of the Academy of Natural Sciences of Philadelphia 109: 177-178.

MAISCH M. W. 2008. — Revision der Gattung Stenopterygius Jaekel, 1904 emend. von Huene, 1922 (Reptilia: Ichthyosauria) aus dem unteren Jura Westeuropas. Paleodiversity 1: 227-271.

Massare J. A., Wahl W. R., Ross M. \& Connely M. V. 2014. Palaeoecology of the marine reptiles of the Redwater Shale Member of the Sundance Formation (Jurassic) of central Wyoming, USA Geological Magazine 151: 167-182. https://doi.org/10.1017/ S0016756813000472

MCGOWAN C. \& MOTANI R. 2003. - Ichthyopterygia. Handbuch der Paläoherpetologie Part 8. Verlag Dr F. Pfeil, München, 175 p.

MOTANI R. 2005. - Evolution of fish-shaped reptiles (Reptilia: Ichthyopterygia) in their physical environments and constraints. Annual Review of Earth and Planetary Sciences 33: 395-420. https:// doi.org/10.1146/annurev.earth.33.092203.122707

Motani R. 2009. - The Evolution of Marine Reptiles. Evolution: Education \& Outreach 2: 224-235. https://doi.org/10.1007/ s12052-009-0139-y

MOTANi R., You H. \& MCGOWAN C. 1996. — Eel-like swimming in the earliest ichthyosaurs. Nature 382: 347-348. https://doi. org/10.1038/382347a0

NAKajIMA Y., HoussaYe A. \& ENDO H. 2014. — Osteohistology of Utatsusaurus hataii (Reptilia: Ichthyopterygia): Implications for early ichthyosaur biology. Acta Palaeontologica Polonica 59: 343-352. http://dx.doi.org/10.4202/app.2012.0045

Romer A. S. 1961. - The Vertebrate Body. W. B. Saunders Company, Philadelphia, $644 \mathrm{p}$.

SANDER P. M. 1992. - Cymbospondylus (Shastasauridae: Ichthyosauria) from the Middle Triassic of Spitsbergen: filling a paleobiogeographic gap. Journal of Paleontology 66: 332-337. https:// doi.org/10.1017/S0022336000033825

SANDER P. M. 2000. - Ichthyosauria: their diversity, distribution, and phylogeny. Paläontologische Zeitschrift 74: 1-35. https://doi. org/10.1007/BF02987949

SAnder P. M., Chen X., Cheng L. \& WAng X. 2011. - Shortsnouted toothless ichthyosaur from China suggests Late Triassic diversification of suction feeding ichthyosaurs. PLOS ONE 6: e19480. https://doi.org/10.1371/journal.pone.0019480

SeITZ A. L. L. 1907. — Vergleichende Studien über den mikroskopischen Knochenbau fossiler und rezenter Reptilien und dessen Bedeutung für das Wachstum und Umbildung des Knochengewebes im allgemein. Nova Acta, Abhandlungen der kaiserlichen Leopold-Carolingischen deutschen Akademie der Naturforscher Akademie der Naturforscher 87: 230-370.

TALEVI M. \& FERNÁNDEZ M. S. 2012. - Unexpected skeletal histology of an ichthyosaur from the Middle Jurassic of Patagonia: implications for evolution of bone microstructure among secondary aquatic tetrapods. Naturwissenschaften 99: 241-244. https://doi.org/10.1007/s00114-012-0886-4

Talevi M., Fernández M. \& Salgado L. 2012. — Variación ontogenética en la histología ósea de Caypullisaurus bonapartei Fernández, 1997 (Ichthyosauria: Ophthalmosauridae). Ameghiniana 49: 38-46. https://doi.org/10.5710/AMGH.v49i1(403) 